\title{
ALBA FUCENS ARCHAEOLOGICAL SITE: MULTISCALE AND MULTIDISCIPLINARY APPROACH FOR RISK ASSESSMENT AND CONSERVATION
}

\author{
M. Alicandro ${ }^{1}$, E. Candigliota ${ }^{2}$, D. Dominici ${ }^{1 *}$, F. Immordino $^{2}$, R. Quaresima $^{1}$, S. Zollini ${ }^{1}$ \\ ${ }^{1}$ Dept. of Civil, Construction-Architecture and Environmental Engineering, University of L'Aquila, via G. Gronchi, 18, 67100 \\ L’Aquila, Italy - (maria.alicandro, donatella.dominici, raimondo.quaresima@univaq.it, sara.zollini@graduate.univaq.it) \\ ${ }^{2}$ ENEA Division Models and Technologies for Risk Reduction, Via Martiri di Monte Sole, 4, 40129, Bologna, Italy - \\ (elena.candigliota, francesco.immordino@enea.it)
}

Commission VI, WG VI/4

KEY WORDS: Alba Fucens, Cultural Heritage, remote sensing, UAV, photogrammetry, risk assessment, conservation

\begin{abstract}
The Latin Colony (303 BC) of Alba Fucens (L'Aquila, Italy) is the largest archaeological area of the whole Apennines. Due to its extension, location and environmental context, the conservation of the site is particularly complex.

For these reasons, in the paper a multiscale and multidisciplinary geoarchaeological study (remote sensing and UAV photogrammetry) of the site, to extract and measure morphostructural information to be associated to the environmental context, risk assessment and conservation, is reported.

The study area is located on a higher geostructure with a subangular shape, which suggests a tectonic origin, with respect to the surrounding plain and bounded to the East by a large fan that takes place towards the Piana del Fucino.

First, the geo-structural analysis, using the Landsat- 8 and GeoEye multispectral sensors, was performed. The GeoEye satellite image allowed carrying out the morphological analysis of the archaeological area, its physical characteristics, the drainage pattern and the land use. Subsequently, after image processing of satellite data, a UAV survey was carried out in some relevant zones. Considering the UAV photogrammetry accuracy information, it was possible to extract data as map producing with several advantages (economic and time saving, minimum field work). With a multiscale and metric approach, the geomatics techniques allowed to deeply investigate some areas, creating detailed 3D models for evaluate risks and the decay. Finally, a general discussion about risk mitigation and conservation is reported.
\end{abstract}

\section{INTRODUCTION}

The greater complexity of conservation, preservation and safeguard of archaeological areas, compared to those of other Cultural Heritage contexts, are related to their extension, environmental and outdoor location and correlated events and anthropogenic factors.

Moreover, in some cases it is possible that strong interactions also occur with close and heavily anthropized urban or, on the contrary, with natural environments rich in biodiversity but subject to hydrogeological risks and/or climatic factors often very severe. For these reasons, the concept of risk for the archeology areas, with its mitigation and management, through tools such as knowledge and conservation, is widely used.

In archaeological contexts the knowledge, respect to the conservation, which provides consolidated best practices of planning and intervention, is particularly complex as it is related not only to the original historical events and destructions, but, above all, to the environmental, territorial, material and anthropic transformations and modifications of the site. Therefore, within numerous available tools Remote Sensing and geomatic techniques are nowadays configured as able to rapidly acquire innumerable cognitive information useful for preparing preventive and conservative interventions for the archeological areas as well as for other Cultural Heritage sites. Instruments essential for risk mitigation, achievable through a planning of the objectives and the improvement and the optimization of the knowledge, result the remote sensing from satellite and Unmanned Aerial Vehicle (UAV) surveys, used in a multi and interdisciplinary approach by various diagnostic and conservative scientific experts. In the paper, a multiscale methodology for the archaeological site of Alba Fucens (L'Aquila) is carried out for risk assessment as well as to plan conservative actions.

\section{STUDY AREA}

\subsection{Brief historical background and archaeological features}

Alba Fucens is considered the most important archaeological site of whole Appenines. According to the Romanization process of the Italic populations the Latin colony of Alba (303 BC) was settled along the ancient Via Tiburtina Valeria and located in a baricentric position, in the Aequi population territory, between the ancient Fucino lake (lacustrine aerea), the mountain of Velino and the only western access from Rome (present Torano village (Rieti, Italy)). The settlement was placed on a plateau, "Piano della Civita" (Plane of the Civita), encircled by three opposed high grounds (S. Nicola, San Pietro and Pettorino). A large defensive system, based on meghalitic walls, gates, ramparts and towers, surrounding the city made it an impregnable fortress due to its position and to the defensive structures organization (Figure 1). During centuries, starting from the earthquake of 346 BC, Alba Fucens was progressively

Corresponding author 
abandoned. The reasons have been identified in the seismicity of the area and in some hydrogeological critical issues (Galadini 2010, 2012, 2015).

During the Middle Ages the settlement of the Civita moved on San Nicola hill with the construction of a small fortified inhabited center and a castle (Orsini castle). Due to recurrent earthquakes also this settlement was abandoned, definitively.

Starting from 1950 to the present day, numerous missions and excavation campaigns have brought to light the current settlement of the Civita.

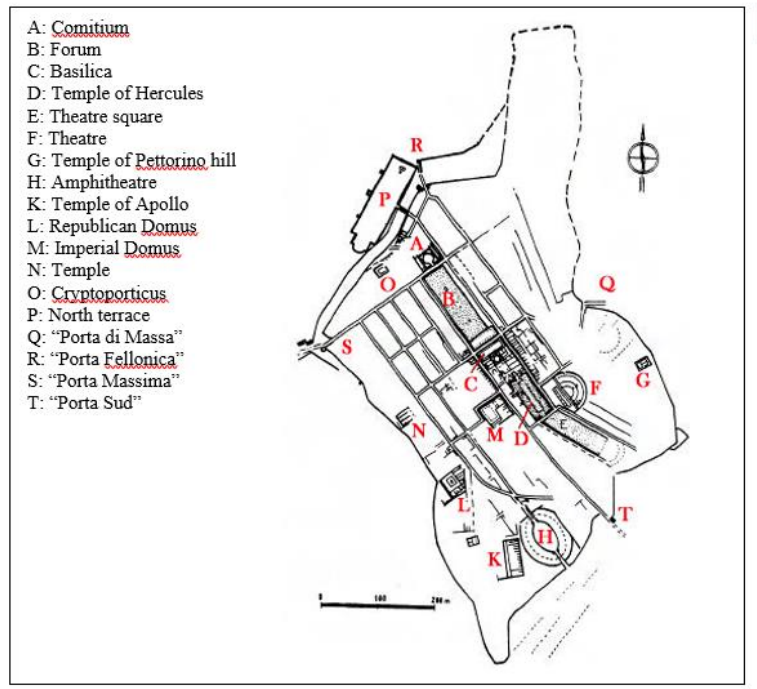

Figure 1. Alba Fucens Archaeological Site (Mertens,1969)

\section{LANDSCAPE GEOARCHEOLOGICAL RECOSTRUCTION}

\subsection{Geological structural and satellite imaging analysis}

The study area is part of the Fucino area, characterized by Meso-Cenozoiccarbonate formations (transition environment, pelagic and platform environment), Neogene terrigenous sequences and plio deposits quaternaries of colluvial, alluvial andustrine origin (Bosi et al., 1995; Miccadei et al., 1997).

Structurally the area is the result of a complex tectonic history linked to the activity, starting from the Pliocene, of two normal fault systems, NE-SW and NW-SE respectively oriented (Galadini and Messina, 1994, Cavinato et al., 2002) (Figure 2). The archaeological site of Alba Fucens is developed on a hilly system of 950-1000 m altitude, at the north-western edge of the Fucino plateau. From a geo-structural point of view the latter is an arenaceous structure of the Middle-lower Miocene (20-15 million BP) and incorporated, above all in the upper Pleistocene (39.500 BP), from the two branches of the Valle Majelama fan that develops from the southern side of the massif of the Velino (Frezzotti and Giraudi, 1992).

Moreover, some general morpho-structural features were extracted through the study of the spectral bands and their RGB color synthesis from the GeoEye data (Figure 3).

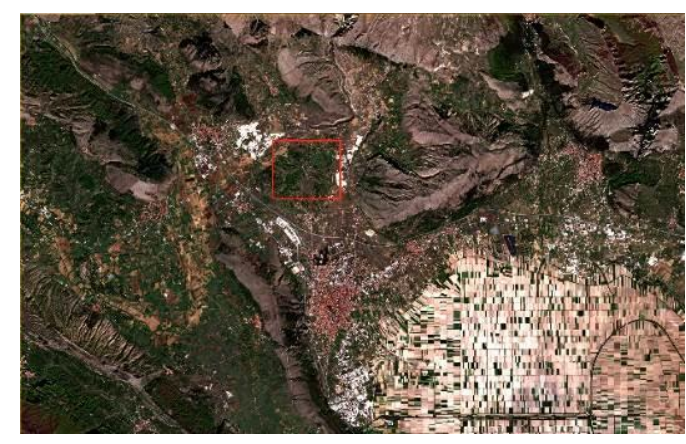

Figure 2. Sentinel-2 image of the study area (red squared box).

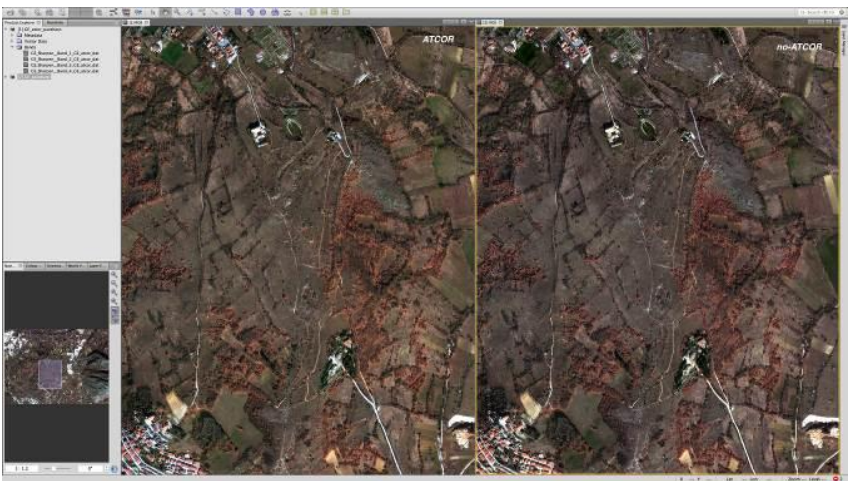

Figure 3. GeoEye raw image (left) and after ATCOR processing (right), $0.50 \mathrm{~m}$ resolution.

\subsection{Morphostructural information by satellite data}

The study area is located on a higher geostructure with a subangular shape, which suggests a tectonic origin, with respect to the surrounding plain and bounded to the East by a large fan that takes place towards the Avezzano Plain.

By superimposing the satellite image on the three-dimensional digital model extracted from the SRTM data, it is possible to observe the relationships between the Alba Fucens arenaceous structure incorporated between the two branches of the Valle Majelama conoid (Figure 4).

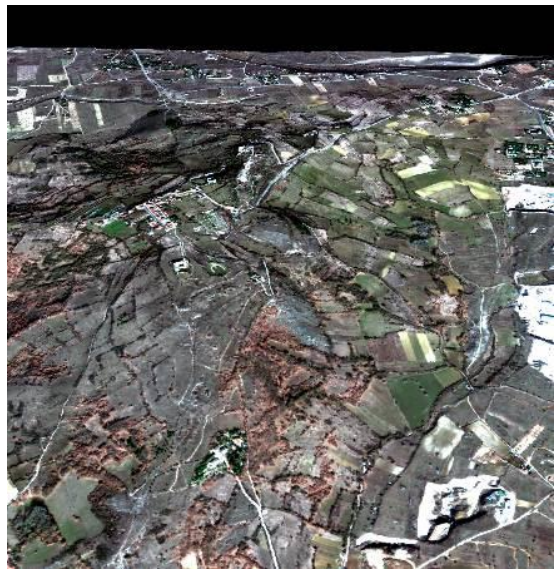

Figure 4. 3D view of the Alba Fucens archaeological site obtained by superimposing the GeoEye satellite scene on the 30m-SRTM DEM. 
During time the valley of Alba Fucens settlements was transformed into a basin of natural sedimentation in which, during the rapid depositional episodes not devoid of destructive energy, pluri-decimetric sludge accumulations containing fragments of the various materials taken up from the mountainsides.

The slopes instability and the consequent deposition of colluvial sediments covering the remains of the ancient town between Late Antiquity and Early Middle Ages are presumably the reflection of processes that have acted on a wider scale and are characterized by a transition from a predominantly humid climate to a tendentially arid climate (Galadini et al., 2011).

These climatic transitions explain the origin of the strong instability and the mobilization of the detritic coverages that have led to the movement of the inhabited center to the progressive abandonment of the city, together with seismic events occured during the centuries, by the ancient populations. A morphological filter has been applied in the GeoEye pansharp multispectral image. The applied morphological filters $\left(45^{\circ}\right)$ highlight some particular features linked to archaeological emplacements and covered by vegetation (Figure 5).

The multispectral satellite investigations allowed to carry on a specific and focused field survey allowing several relevant considerations discussed below. In Geo-Eye image, the existing defensive walls are clearly visible; a hypothetical reconstruction of the parts that are no longer visible has been traced (Figure 6), followed by a survey on site.
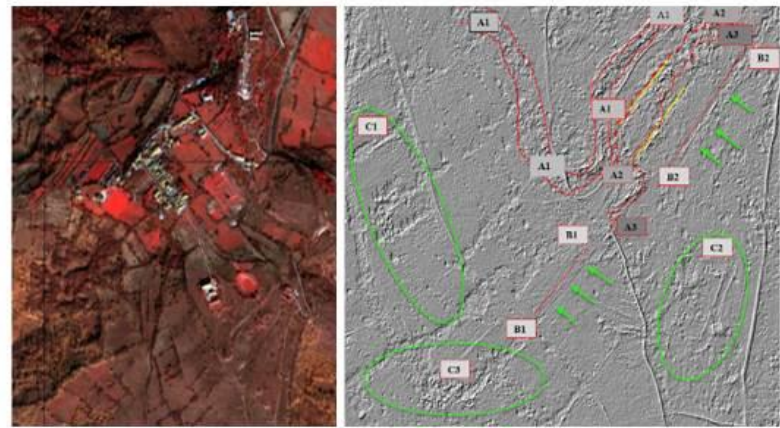

Figure 5. Morphological filters $\left(45^{\circ}\right)$ highlight some particular features linked to archaeological emplacements observed in ground surveys. Detail of the RGB color representation of the Geo-Eye multispectral image; morphological filters $\left(45^{\circ}\right)$ highlight quarries (A1, A2, A3) and other archaeological defensive structures (B1, B2) $(\mathrm{C} 1, \mathrm{C} 2, \mathrm{C} 3)$ covered by debris and vegetation.

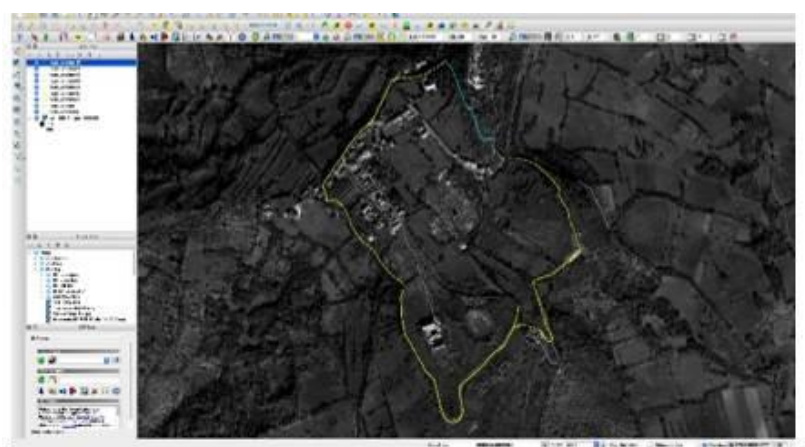

Figure 6. The megalithic certain walls, (yellow continuous line), hypnotized, (yellow dotted line) and probable tracks (cyan dotted line) superimposed to GeoEye geocoded satellite image.

\subsection{UAV photogrammetry survey}

The main topics of the archaeological site of Alba Fucens concern the settlement of the Civita and the megalithic walls. In order to understand the state of conservation of the megalithic walls, in several areas, UAV photogrammetry surveys were performed. It has been known the great advantages achievable by the UAV photogrammetry (Baiocchi et al., 2013; Dominici et al., 2016) for the Cultural Heritage study. UAV photogrammetry is a good tool to obtain detailed and metric 3D model (Barazzetti et al., 2011; Blaschke, 2010; Roncella et al., 2011; Triggs et al., 1999) covering wide areas and in short time. In this context, the 3D model was useful to understand and quantify the degradation phenomena such as collapse, washout and cracking. Due to accessibility and vegetation problems, the UAV survey and few possible flights were focused on megalithic northern walls close to "Porta Fellonica".

To obtain the 3D model, an initial survey planning should be achieved to guarantee a good overlap between images and to establish the final GSD (Ground Sample Distance) in function of the sensor focal length and the height or distance flight (Table 1).

\begin{tabular}{|c|c|c|}
\hline \multicolumn{2}{|c|}{ Camera } & Sony alpha 6000 \\
\hline \multicolumn{2}{|c|}{ Resolution } & $24 M P$ \\
\hline \multicolumn{2}{|c|}{ Focal length } & $16 \mathrm{~mm}$ \\
\hline \multirow{2}{*}{$\begin{array}{c}\text { Sensor } \\
\text { dimensions }\end{array}$} & width & $24 \mathrm{~mm}$ \\
\hline & height & $16 \mathrm{~mm}$ \\
\hline \multicolumn{2}{|c|}{ Pixel dimension } & $4.3 \mu \mathrm{m}$ \\
\hline \multicolumn{2}{|c|}{ Weight } & $345 \mathrm{~g}$ \\
\hline
\end{tabular}

Table 1. Sensor parameters

The UAV flights with aerial and vertical route were planned on vegetation free areas to obtain a complete wall's "scenario". The flights has been set a $50 \mathrm{~m}$ of altitude/distance, both for the aerial and the vertical route, obtaining about $1 \mathrm{~cm}$ of GSD and with $80 \%$ overlap and $70 \%$ sidelap. 41 images has been taken over for the aerial survey (Figure 7) and 25 for the vertical one.

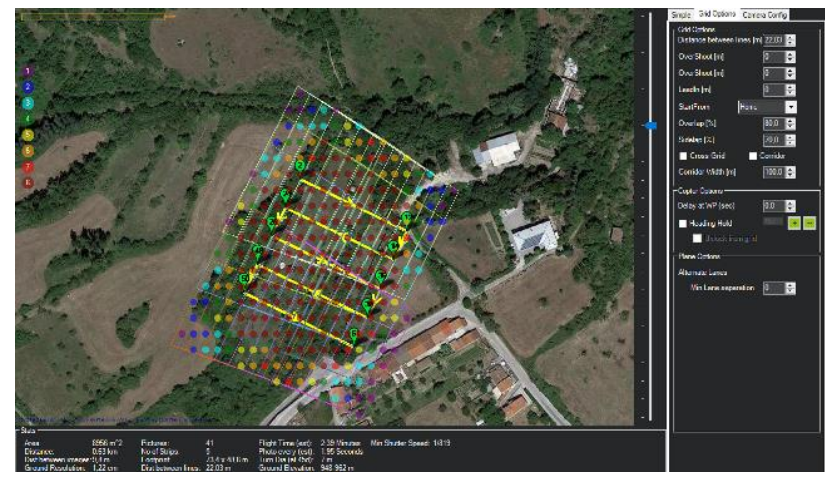

Figure 7. Flight planning for the aerial survey.

The acquired images were processed with Agisoft Photoscan, a tool that combine the photogrammetry equations with the new algorithms of the Structure For Motion and Multi-Stereo View. The data treatment allows obtaining the internal and external orientation parameter (Kraus, 1994) to reconstruct the 3D model. During the elaboration, 6 Ground Control Points (GCPs) have been used of georeferencing and 4 Check Points to evaluate the quality of the results. The results obtained are the 3D model, DEM (Digital Elevation Model) and Orthomosaics (Figure 8). The first outputs allow starting detailed in-situ investigations on conservative state of the walls. 
DEM

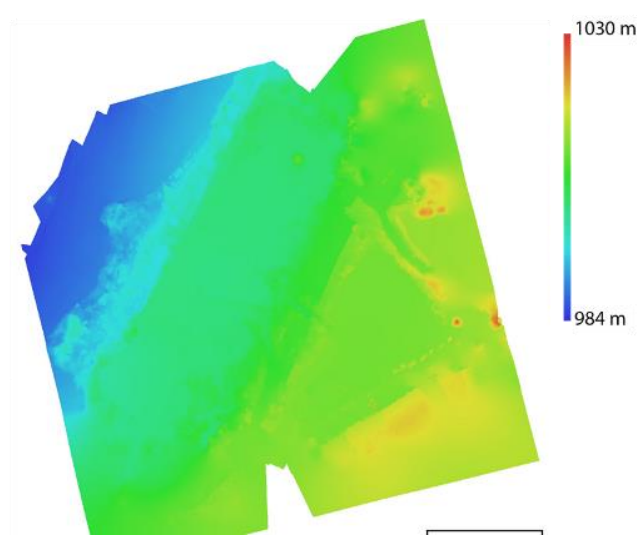

\section{Point Cloud}

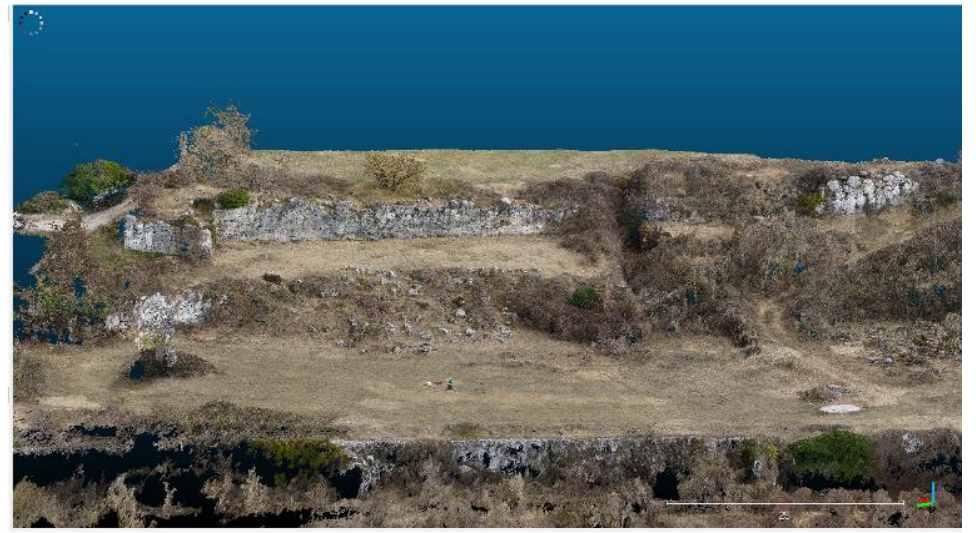

Figure 8. Output of UAV photogrammetry Survey: DEM and Point Cloud.

\subsection{In situ survey: risk assessment and state of conservation}

The remote sensing allowed mapping the entire perimeter of the wall structures and highlighting the inaccessibility of many areas due to the presence of vegetation. The in-situ survey of the megalithic northern walls (Figure 9) shown that the collapse of the lower wall produced the landslide of the terracing; it was also possible to observe, on the upper wall, local collapse phenomena (yellow arrow) and the instability of some blocks (red spotted marks). To quantify the instability, further analysis on the point cloud into Cloud Compare were conducted and some profile are shown in Figure 9.

Many areas were interested by washout (red-circled zone), vertical cracks (dashed yellow line) and lack or cracking of blocks (orange marked zones).

In other zones, the field inspections have shown similar structural and aesthetic conservative problems of the walls. The former are due to instability and landslide phenomena and the presence of vegetation.

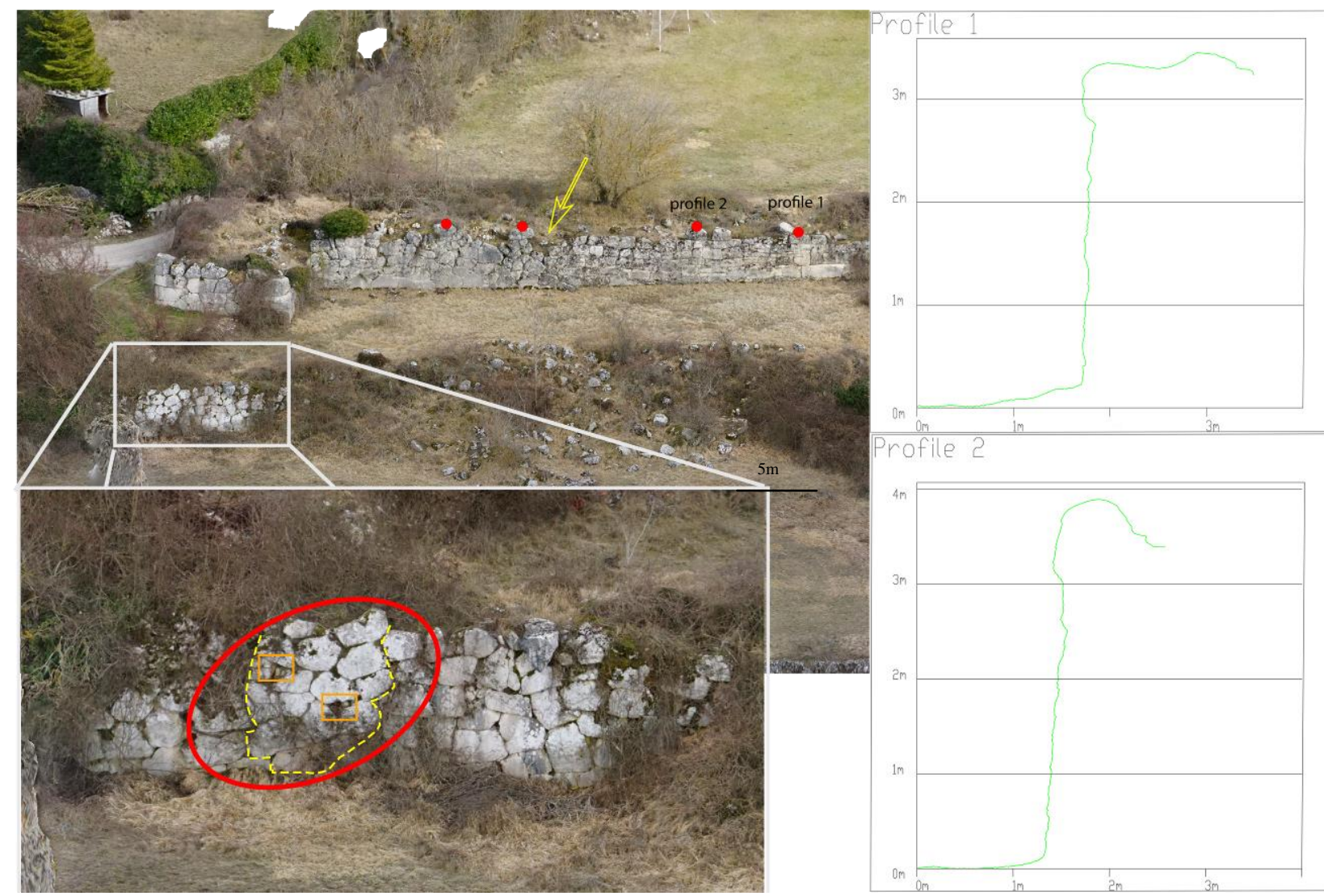

Figure 9. Degradation phenomena on the orthomosaic of the northern walls (left) and profile of the instability blocks of the walls (right). 
Along the perimeter, different deformation phenomena of the walls were observed with out-of-plane rotation, out (even of $12^{\circ}$ measured at the centerline) or opening of the walls (off-plan action) respectively with loss of the upper part of the structures and/or expulsion of several blocks or with formation of vertical cracks (Figures 10-13). At least, in few survived wall corners was observed the loss of clamping and perpendicularity of the structure with production of cracks.

No water stagnation zones were detected. However, it is believed that part of the structural problems and weathering of the wall masonries are also associated with the washout and the leaching of rainwater from and to the Piano of the Civita as detected on the surface of some walls (Figures 10-12).

As secondary structural decay phenomena must be mentioned, inside of the walls, the loss or the cracking (compressive strength due to vertical loads or geological features - stratified lithological bedding planes) of some isolate blocks (Figures 1011).

The risk of collapsing of the masonry structures or instability of single blocks is considered high for those walls 4-5 meters high in which instability problems have been detected.

Also the consolidating function (geotechnical aspect) of the wide and extensive terraces realized on the slopes or on the half-coast of the megalithic walls must be also carefully taken into account (Figures 10, 13).

Vegetation and trees growing behind, inside and above the walls contribute to the structural instability and represent a risk in case of fire or arson (Figures 11-13).

Finally, concerning the state of conservation of the wall structures, it must be considered the high seismicity of the territory and the events occurred in the past.

Unlike the archaeological settlement of the Civita, the lack of paths and walkways on the surroundings produces land run-off and preferential water runoff.

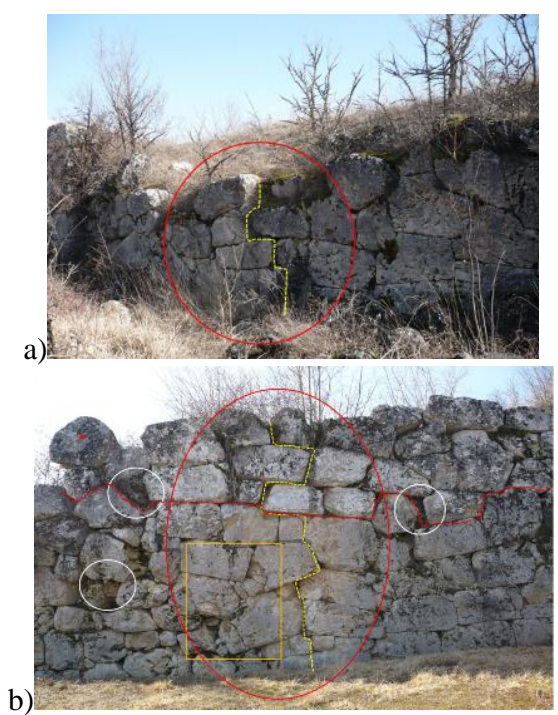

Figure 10. Megalithic walls a) left and b) right side of "Porta di Massa". It is possible to observe the vegetation inside and above the walls, the washout (red circled zone), the bending (dashed yellow line) and the out-of-plane rotation (red dashed line), past maintenance interventions (the cutting of roots inside the wall (white circled zone)), cracking of the blocks (orange squared zone) produced by vertical actions. Single blocks instability (red spotted mark-top left) is reported.

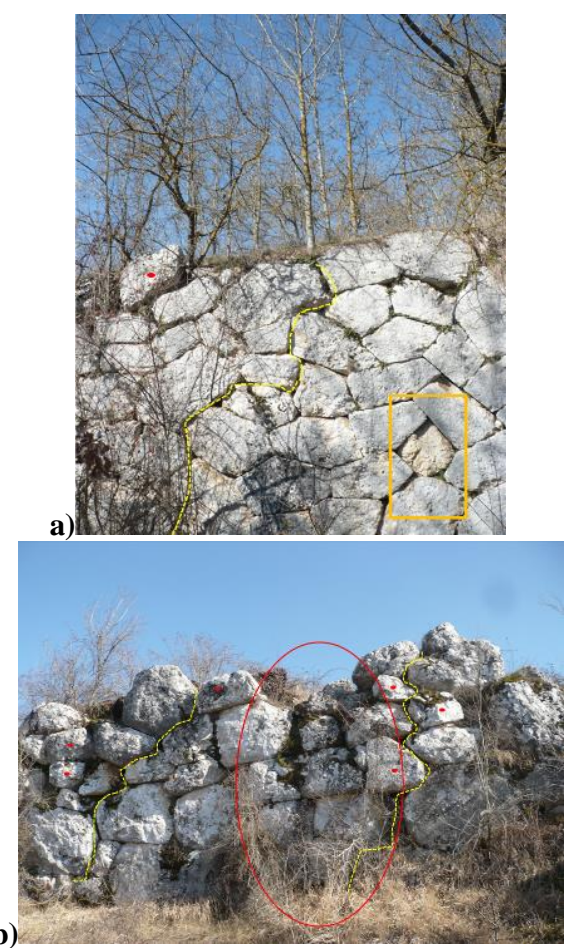

Figure 11. Megalithic a) southern and b) northern (close to "Porta Fellonica") walls. It is possible to observe the vegetation above the walls, the decay of a block (orange squared zone), the washout (redcircled zone), the bending (dashed yellow line) and the instability of some blocks (red spotted marks).

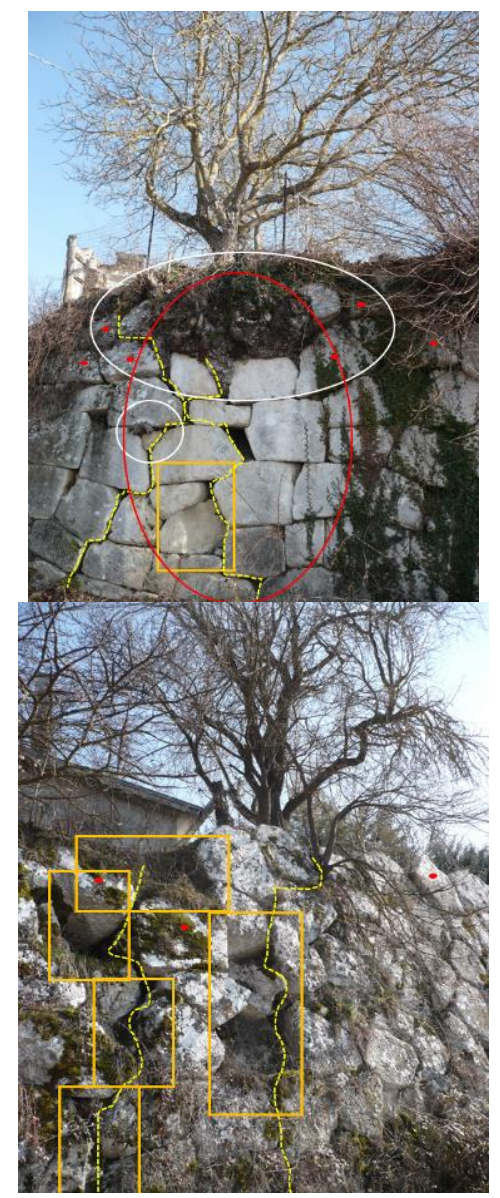

Figure 12. Megalithic retaining walls of the Provincial Road 24 (SP 24 per Alba Fucens): washout phenomena (red circled 
zone), structural instability (dashed yellow line), roots inside the structure (white circled zone), cracking or loss (orange marked zones) or instability (red spotted mark) of blocks. To be notice the houses and the vegetation above the wall.

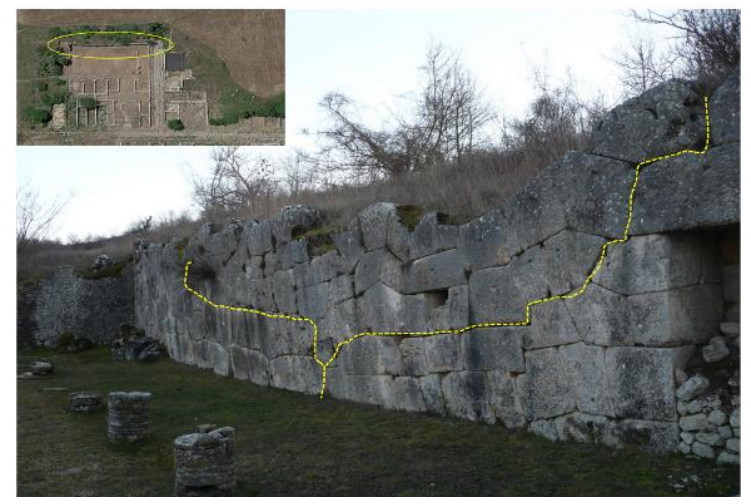

Figure 13. Megalithic wall near of the Imperial house and geotechnics function in preventing landslide: the loss of plumb line with tilting of a wall portion and production of instability phenomena (yellow dashed lines) is reported. The deformation of the wall is well observable even by common aerial application (left top frame).

\section{CONSIDERATIONS ON RISK MITIGATION AND CONSERVATION}

Concerning risk mitigation the cutting of the vegetation adjacent to the megalithic walls is proposed. A part a reduction of the instability of the walls, as well as the fire risks, it will be possible perform detailed inspections and further monitoring activity (UAV). Considering that many plant species are repopulating essences it will be necessary their devitalization to prevent re-vegetation phenomena and possible infections.

To avoid a radical transformation of the landscape and possible consequences on slope stability, wood cutting should be carried only near the walls.

Afterwards will be possible execute structural interventions to prevent collapses or instability of blocks. For this aim the blocks, after a careful relief, can be removed or repositioned (shield anchor bolts and eyebolts) in order to recovery the instability or the tilting. Crashed or missing blocks could be replaced with new ones according to the best practices (theory of restoration) of minimal interventions, distinguishability, reversibility and physical and mechanical compatibility.

The slope stabilization and drainages must be better understood and investigate due to its complexity, interventions and costs. All possible interventions should be carried out according to natural engineering principles and materials.

By means of remote sensing will be possible to identify all the current paths and walkways out of the Civita in order to delimited them and design correct tracks to reduce damage from erosion and shortening of the route. Sign and signposts will help visitors to appreciate the archaeological site while respecting its conservation.

\section{FUTURE TRENDS}

Concerning the site of Alba Fucens, the preliminary and multidisciplinary geoarchaelogical approach allowed to acquire geological, morphostructural and environmental information. To better define risk assessment, its mitigations and conservative actions it is necessary the cutting of the vegetation around the walls.
In this favourable conditions, it will be possible to plan the UAV flights, in order to obtain 3D models for a metric characterization of the megalithic walls focusing on the structural aspects.

\section{REFERENCES}

Baiocchi, V., Dominici, D., Mormile, M., 2013. UAV application in post-seismic environment. Int. Arch. Photogramm. Remote Sens. Spatial Inf. Sci., XL-1 W 2, 21-25.

Barazzetti, L., Forlani, G., Remondino, F., Roncella, R., Scaioni, M., 2011. Experiences and achievements in automated image sequence orientation for close-range photogrammetric projects, in: Remondino, F., Shortis, M.R. (Eds.), . pp. 80850F80850F-13. https://doi.org/10.1117/12.890116

Blaschke, T., 2010. Object based image analysis for remote sensing. ISPRS Journal of Photogrammetry and Remote Sensing 65, 2-16. https://doi.org/10.1016/j.isprsjprs.2009.06.004

Bosi, C., Galadini, F., Messina, P. 1995. Stratigrafia pliopleistocenica della conca del Fucino. Quaternario 8, 83-94.

Cavinato, G.P., Carusi, C., Dall'Asta M., Miccadei, E., Piacentini, P. 2002. Sedimentary and tectonic evolution of Plio-Pleistocene alluvial and lacustrine deposits of Fucino Basin (central Italy). Sedimentary Geology 148, pp. 29-59.

Dominici, D., Alicandro, M., Massimi, V., 2016. UAV photogrammetry in the post-earthquake scenario: case studies in L'Aquila. Geomatics, Natural Hazards and Risk 0, 1-17. https://doi.org/10.1080/19475705.2016.1176605

Dominici, D., De Berardinis, P., Alicandro, M., \& Rotilio, M., 2018. Photogrammetry from UAV in the recovery interventions: from the pre-planning phase to the construction site. GEOmedia, 22(1), 6-10. Available: <http://mediageo.it/ojs/index.php/GEOmedia/article/view/1518/ 1378> Last access: 02 gen. 2019

Fernández- Hernandez, J., González- Aguilera, D. Rodríguez- Gonzálvez, P., \& Mancera- Taboada, J. 2015. Image- based modelling from unmanned aerial vehicle (UAV) photogrammetry: an effective, low- cost tool for archaeological applications. Archaeometry, 57(1), 128-145.

Frezzotti M., Giraudi C., 1992, Evoluzione geologica tardopleistocenica ed olocenica del conoide complesso di Valle Majelama (Massiccio del Velino, Abruzzo), in Il Quaternario 5 (1), Roma, pp. 33-50.

Galadini, F., Messina, P. 1994. Plio-Quaternary tectonics of the Fucino basin and surroundings areas (central Italy), Giornale di Geologia 56(2):73-99

Galadini F., Falcucci E. Gori S., 2011. Indagini per la caratterizzazione dei rischi naturali presso siti archeologici della Marsica ed aree limitrofe. Atti del III Convegno di Archeologia "Il Fucino e le aree limitrofe nell'antichità".Avezzano1315novembre2011,pp.339-350.

Galadini, F., Ceccaroni, E., Falcucci E. 2010 Archaeoseismological evidence of a disruptive Late Antique 
earthquake at Alba Fucens (central Italy), Bollettino di Geofisica Teorica ed Applicata 51 (2):143-161.

Galadini, F., Ceccaroni, E., Falcucci E., Gori, S. 2012. Le fasi di colluviamento tardoantiche nel Piano della Civita e la fine della frequentazione dell'abitato di Alba Fucens. Atti del Convegno in memoria di Joseph Mertens, Academia Belgica, 46 2008, Bruxelles-Roma, 187-199.

Kraus, K., 1994. Fotogrammetria Vol.1. Libreria universitaria Levrotto \& Bella, Torino.

Mertens, J. 1969. Alba Fucens, Rapports ed Etudes. Centre Belge de Recherches archéologiques en Italie Centrale $e$ Meridionale, XII, Roma.

Miccadei, E., Barberi, R. \& De Caterini, G. 1997. Nuovi dati geologici sui depositi quaternari della Conca Subaequana (Appennino abruzzese). Il Quaternario, Italian Journal of Quaternary Sciences, 10 (2), 483-488, Roma.

Roncella, R., Re, C., Forlani, G., 2011. Performance evaluation of a structure and motion strategy in architecture and cultural heritage. Int. Archives of Photogrammetry, Remote Sensing and Spatial Information Sciences 38, 285-292

Triggs, B., McLauchlan, P.F., Hartley, R.I., Fitzgibbon, A.W., 1999. Bundle adjustment - a modern synthesis, in: International Workshop on Vision Algorithms. Springer, pp. 298-372. 